\title{
The Effect Of Corporate Governance On Corruption In Public Listed Companies In The Context Of Jordan
}

\author{
Mohamed Fahmi Ghazwi, \\ Assistant Professor, Deputy Dean of Faculty of Law, Al-Zaytoonah University,Jordan, m,ghazwi@zuj.edu.jo .
}

\begin{abstract}
The OECD defined corporate governance as, enforce laws, rules and standards that define the relationship between company management on the one hand, shareholders, stakeholders or parties associated with the company on the other, and urge financial institutions to adopt those laws and standards in their systems to ensure universal classification, such laws and standards are called corporate governance. Some countries have adopted such standards, which are based on integrity and transparency, such as the Hashemite Kingdom of Jordan, but the apply these standards to protect the minority of shareholders in the joint stock companies are in conflict with certain legal provisions laid down by the Jordanian legislature in the companies Act. The Jordanian companies law and some other financial laws have, of course, included a number of factors that encourage corporate governance, but on the other hand, we find texts that still impede the application of these standards and provide indicators that do not encourage the application of their standards and affect the rights of minority shareholders. The study will refer to the most important corporate governance criteria that balance the rights of the minority and majority shareholders with those that still need to be modified.

Keywords:
\end{abstract}

Corporate governance, shareholder rights, transparency, public listed company

Article Received: 18 August 2020, Revised: 3 November 2020, Accepted: 24 November 2020

\section{Introduction}

Many countries are still looking at a way to create a legal system that examines the corporate governance of joint-stock companies as one of the companies that play an important role in increasing economic growth.

Businesses in general have become increasingly important, and joint venture firms in particular are important, which depend on capital accumulation are of great importance in the free-market economy. As some say, "it is the most important product of the capitalist system, because it is a legal structure through which this system can penetrate and spread in the national and international fields ${ }^{1 "}$.

If we want to be in front of a joint-stock company that has a role in the economic development of the

\footnotetext{
${ }^{1}$ Muhammad Khaled Al-Yaseen The Legal System for the Governance of Joint Stock Companies A Comparative Study of Kuwaiti and Egyptian Legislation Dar Al-Nahda AlArabiya, Cairo, 2018. Pg. 17.
}

state, we must achieve equality between shareholders' rights and the rights of the founders, and separate money from the administration. By doing so, we can ensure that they do not control and invest profits with the pretext of logic and some legal texts giving them the right to do that. In addition to, the lack of accountability, control and supervision means, the shaking confidence of those dealing with companies, this leads to the need to establish a system that achieves integrity and transparency ${ }^{2}$.

Corporate governance maximizes the company's value and reinforces its competitive position in markets, enabling it to attract domestic and global sources of finance for expansion and growth and creating new jobs, leading to the required

${ }^{2}$ Dr. Saleh Al-Okdah and others, Article on Institutional Governance in Jordan - Reality and Aspirations, The Third Scientific Conference of the Faculty of Economics and Administrative Sciences, Applied Sciences Private University - Jordan, published in the Jordanian Journal of Applied Sciences, issued by the Private University of Applied Sciences, August 4, 2019, p. 2. 
efficiency and economic development. The international community has been able to take a step in the right direction under corporate governance, becoming overshadowed by the style and pattern of corporate governance. It has become urgent to implement its rules, especially in the light of globalization and the opening of markets, as well as the recent economic crises and specific ones in the Hashemite Kingdom of Jordan. This has done great damage to shareholders, creditors, suppliers and the public ${ }^{3}$.

\section{\# The problems of the study:}

The problem of the study lies in the extent to which joint stock companies in Jordan apply corporate governance in order to fight and limit corruption.

\section{\# The Questions of the study}

- The role of corporate governance in setting controls to ensure equity and equality for all stakeholders in Jordan to limit the corruption.

- The role of corporate governance in protecting the rights of stakeholders.

- The role of corporate governance in strengthening the rule of law against corruption through the application of the principle of transparency.

- The application of the principle of justice and equality contributes to a significant improvement in performance.

\section{\# The importance of the research}

The importance of this research appears due to the increasing interest in corporate governance of joint-stock companies, according to developing a set of laws, regulations and decisions. These laws and decisions aim to control and monitor the work of these companies in order to protect its property on the one hand, and to achieve quality and excellence in performance on the other hand, by choosing methods. This method regulates the relationships between the main parties that affect performance, and what corporate governance encourages in terms of optimal use of resources,

${ }^{3}$ Abdel Sabour Abdel Qawi Ali Masri, Legal Regulation for Corporate Governance - A Comparative Study - pg. 11.

www.psychologyandeducation.net achieving sustainable growth, and encouraging productivity. These laws and rules focused on transparency, integrity and fairness and facilitated the process of monitoring and overseeing performance.

\section{Research objectives:}

- Recognize corporate governance and its importance.

- Learn about Corporate governance principles through which corruption can be reduced.

- Corporate governance limits corruption in joint stock companies.

Research methodology

The researcher used a doctrinal legal research methodology and comparative legal research methodology in a few parts. As far as this study is concerned, the research used doctrinal legal research, as it is a form of qualitative research. In regard to the doctrinal legal research, it queries the relevant law on a particular issue and it covers the analysis of the legal doctrine along with its development and application. The doctrinal legal research is also referred to as pure theoretical research. ${ }^{4}$ Therefore, the doctrinal or pure theoretical research has its basis on the rational approach involving discussion, argument and explanation, and opinions surrounding a legal issue or query. This study requires that the concept of corporate governance be defined in the scope of participating companies. Corporate governance, or what Jordan legislation calls corporate governance, is a framework within which to limit the contribution of companies, but this legal framework must define its criteria for achieving the goal. A mechanism must be provided for the implementation of these standards, so our study in this requirement should be divided into three important topics that address in section I the concept of corporate governance, and section II will be in the international and

${ }^{4}$ Khushal Vibhute and Filipos Aynalem, "Legal Research Methodology", Chilot Word Press, (2009), p.23. 
internal standards of corporate governance and how to apply them in the Hashemite Kingdom of Jordan. Section III will deal with the role of corporate governance to limit the corruption in the joint-stock companies.

Therefore, this part describes the process adopted throughout the study, as well as the methodology

\section{* Section I: The concept of corporate} governance

Undoubtedly, the concept of corporate governance, particularly corporate governance, is a subject of controversy between interested legal and economic doctrine and concerned organizations, and there is no unified concept defined yet. As a result, there are many definitions of different research and jurisprudence views to define its concept.

Before we go into these definitions, it can be said that the doctrine differs in the definition of the term "corporate governance corporate", as some have called it good corporate governance or corporate governance, while others call it institutional control. In fact, the corporate governance can be interpreted as fitting the term "globalization" and "privatization."

The Arab jurisprudence defines corporate governance as, "a state, process, and current, and at the same time a combination of them. It is a vital health and safety factor, as well as an immunity, protection and effective system, govern the movement, and protect and ensure the integrity of all behaviors, the integrity of corporate behavior, and for which it makes an effective safety fence and barrier ${ }^{5}$.

Others define it legally as, "It refers to the nature of the contractual relationship that defines and shows the rights and duties of shareholders, stakeholders and managers on the one hand, and managers on the other." It is not a common definition for jurists, as they define corporate

${ }^{5}$ Mohsen Ahmed Al-Khudairi, Corporate Governance, First Edition, the Arab Nile Group, Cairo, 2015, p. 53 and beyond.

www.psychologyandeducation.net governance according to the thoughts of jurisprudence . $^{6}$.

Some others defines it from accounting doctrine: "It is a set of rules, practices and controls that aim to ensure that management uses the company's physical and moral assets faithfully to the benefit of shareholders and other stakeholders of the company from exercising their rights and protecting their interests." Others also briefly define it, "deepening the role of monitoring and monitoring performance".

However, the definition that has been imposed globally is that of the OECD, which states, "corporate governance is the set of regulations and organizational structures that clarify the responsibilities and duties of different levels of management in the organization, its board of directors, its shareholders, and the relevant stakeholders of the institution to achieve its objectives. In a way that makes it easier to find the adequacy of the provisions of an effective control law, thus helping to make the most efficient and profitable use of the enterprise's resources. ${ }^{7 "}$

In view of the importance of corporate governance and the concepts that it has acquired, many international institutions have been keen to address this concept with analysis and study. The World Bank, the International Monetary Fund and the Organization for Economic Cooperation and Development (OECD), which established the foundations and standards of corporate governance in 1999, are led by the efforts of member and non-member countries to develop the legal and basic system for the purposes of applying corporate governance of all kinds. By providing a variety of guidance to support the management of these companies, the OECD defined corporate governance as: "A set of relationships among the management of the company, the management council of directors, the shareholders' campaign, and other

${ }^{6}$ Muhammad Khalid Al-Yaseen, previous reference, p. 41. ${ }^{7}$ OCED, OCED principles of corporate governance (22) 2016, p.22 
shareholders." on 22/04/2004, (30) countries have agreed on the principles and standards of corporate governance established by the organization. $^{8}$

In the Jordanian Corporate governance Rules Manual issued by the Corporate Control Service, Corporate governance is defined as, "the system by which the company is directed and managed, and the corporate governance structure determines the distribution of rights and responsibilities among the various corporate participants, and the corporate governance structure sets out rules and procedures for decision-making. ${ }^{9 "}$

\section{* The importance of corporate} governance

The importance of corporate governance, and its positive impact on shareholders and their owners in strengthening the economy, is an effective way to develop economic development, especially after the Enron bankruptcy crisis in the United States of America and some East Asian countries in 2001. As results, the World Bank's presidency has urged these countries to follow ways and means to achieve positive and sound corporate governance, thereby strengthening the national economy.

John Hopkins, University lecturer John Sullivan, in an essay entitled instilling corporate governance in emerging and Transitionaldeveloping economies, says, "There are few things that can outweigh the importance that corporate governance attaches to international business and development programs. This is because major companies are collapsing and financial scandals are on the rise.

\footnotetext{
8 Abd Al-Sabour Abdul-Qawi, previous reference, P.15.

9 Dr. Ashraf Gamal El-Din, Corporate Governance Requirements and Financial Markets, His paper submitted to the Conference on "Corporate Governance Requirements and Arab Capital Markets held in Sharm El-Sheikh, Arab Republic of Egypt, May 2017, published in the conference proceedings folder issued by the Arab Organization for Administrative Development, p. 1
}

www.psychologyandeducation.net
Corporate governance is one of the most important processes necessary to ensure that companies operate well and that management is honest in order to fulfill their obligations and commitments, to ensure that enterprises achieve their objectives legally and economically, and to provide quality control and performance development, thereby contributing to the interests of all parties, including:

Firstly, the importance of corporate governance for the Shareholders:

- Full disclosure of the facility's performance, financial situation, and decisions taken by senior management helps shareholders determine the risks involved in investing in these facilities.

- Helping to ensure the rights of all shareholders such as the right to vote, the right to participate, and decisions regarding any material changes that may affect the performance of the enterprise in the future.

Secondly, the importance of corporate governance for the company

- It sets the regulatory framework within which the objectives of the business can be defined by providing appropriate incentives for board members and executive management to achieve the objectives of the stakeholder organization.

- Corporate governance institutions gain the confidence of the tenants because corporate governance rules ensure that their rights are protected.

- Enable increase the economic efficiency of the enterprise by establishing the basis for the relationship between the directors of the enterprise, the board of directors and shareholders

- It is aimed at opening up to global financial markets and attracting a broad 
base of tenants to finance expansion projects. If enterprises do not rely on foreign forms, they can increase domestic confidence and thus increase the money base at a lower cost

\section{Section II: Principles of corporate governance:}

The application of rules of corporate governance has emerged in Jordan's public-sector contributor companies after the approval of the Guide to Corporate governance Rules for Public Shareholding Companies Listed in the Amman Stock Exchange in 2008, and it must be applied from the beginning of 2009. The corporate governance manual has been completed with a goal of establishing clear guidelines governing relations and issues, defining rights, duties and responsibilities in order to achieve the company's goals and objectives and preserve the rights of the parties with the interests associated with them. These rules are based on a number of legislation, which is based on the Financial Securities and legislation Act, and the Companies Act, which incorporated the principles set out by the Organization for Economic Cooperation and Development (OECD) (Financial Securities Commission, 2008) ${ }^{10}$ and contains a code of rules that governed the listed companies of the Amman Stock Exchange (Amman). In 2010, the Financial Securities Commission (CSRC) presented a detailed catalog of the rules of corporate governance to determine rules of procedure and rules of order. The firms should be able to limit compliance with the rules of procedure and under the control of the political authorities, and the rules of practice, which are the focus of the study, are applied through the Obligation to interpret the non-obligation (Comply or explain method). The companies should be required to comply with the rules of the directive to explain the noncompliance in the event of non-compliance with any of these rules (the Financial Securities Commission, 2010). This was preceded by the

\footnotetext{
${ }^{10}$ Corporate Governance Guidebook, Securities
} Commission, 2008 central bank issuing the government's guide to banks and issuing the appropriate regulatory structures to comply with the regulations of the governor. Table (3) shows in detail the evolution of the CORPORATE GOVERNANCE in JORDAN ${ }^{11}$. 11 Organization for Economic Co-operation and
Development (OECD) Principles of Corporate Governance
2004 
Table (3), Development of the corporate governance in Jordan

\begin{tabular}{|c|c|c|}
\hline The entity & \begin{tabular}{|c} 
The \\
year
\end{tabular} & Version \\
\hline $\begin{array}{r}\text { Central } \\
\text { bank } \\
\text { Jordanian }\end{array}$ & 004 & $\begin{array}{l}\text { To issue a } 2004 \text { Handbook of Guidelines for the members of the Bank Board } \\
\text { of Directors The domain of the companies was governed by the ruling guide, } \\
\text { which was established for the banks of Jordan, } 2007\end{array}$ \\
\hline $\begin{array}{l}\text { Insurance } \\
\text { Board }\end{array}$ & 2006 & $\begin{array}{l}\text { To issue instructions to the governor, who is established and established to } \\
\text { administer the companies of the two congregations }\end{array}$ \\
\hline $\begin{array}{r}\text { Central } \\
\text { bank } \\
\text { Jordanian }\end{array}$ & 007 & $\begin{array}{l}\text { The Institutional Corporate governance Guide was issued in } 2007 \text {, must be } \\
\text { applied from } 12 / 31 / 2007 \text {, and contains provisions and procedures that each } \\
\text { bank must disclose in the annual report in the manner of commitment and } \\
\text { explanation of non-compliance. (Institutional Corporate governance Guide } \\
\text { for Jordanian Banks, 2007) }\end{array}$ \\
\hline $\begin{array}{l}\text { Securities } \\
\text { Commission }\end{array}$ & 2008 & $\begin{array}{l}\text { The issuance of corporate governance rules is binding on public shareholding } \\
\text { companies listed on the financial market to disclose the application of the } \\
\text { rules, and they had to be applied as of 1/1/2009 (The Securities Commission } \\
\text { 2008) }\end{array}$ \\
\hline $\begin{array}{l}\text { Securities } \\
\text { Commission }\end{array}$ & 2010 & $\begin{array}{l}\text { Issuing the detailed index of corporate governance rules, and mandatory } \\
\text { rules (general and jus cogens) have been defined as guidelines (The Securities } \\
\text { Commission, 2010) }\end{array}$ \\
\hline $\begin{array}{l}\text { Companies } \\
\text { Control } \\
\text { Department }\end{array}$ & 2012 & $\begin{array}{l}\text { The issuance of the Jordanian Corporate governance Manual (private joint } \\
\text { stock companies, limited liability companies, and public shareholding } \\
\text { companies not listed on the stock exchange) based on a memorandum of } \\
\text { understanding signed with the International Finance Corporation (IFC) in } \\
\text { 2011, where the guide targeted small and medium-sized companies that are } \\
\text { not covered by the issued corporate governance rules For the Central Bank, } \\
\text { Insurance Authority, or Securities Commission (Companies Control } \\
\text { Department, 2012) }\end{array}$ \\
\hline
\end{tabular}

\section{* Corporate governance rules for joint stock companies listed on the Amman Stock Exchange}

The corporate governance rules for public jointstock companies in the corporate governance Manual are divided into four sections, which are rules related to the company's board of directors, rules related to general assembly meetings, rules related to shareholder rights, and rules related to disclosure and transparency. These rules are derived from the international principles approved

www.psychologyandeducation.net by the Organization for Economic Cooperation and Development (OECD) (The Securities Commission, 2008). Some of which are based on binding legal texts contained in a number of legislations approved before the emergence of the corporate governance framework, such as the Securities Law and the legislations issued 
pursuant to it, and the Jordanian Companies Law $^{12}$.

\section{Rules related to the board of directors of the public joint stock company}

A number of mechanisms included in the rules were discussed by the Board of Governors, which aim at achieving the objectives of the Board of Governors and related committees and meetings .

\section{a) The number of members of the Governing Council}

The corporate governance ' rules were recommended that the members of a Board of Directors were at least five persons and a maximum of thirteen (the Financial Securities Commission, 2010). The Jordanian Companies Law in Article 132 / A specified the number of board members to be no less than 3 and no more than 13 people (Companies Law, 1997). The OECD Corporate governance Principles did not directly cover the issue of the number of members of the board of directors and did not suggest a specific number. However, they emphasized the convergence of all the basic features, which are among the best ways to advance the facilities, such as protecting shareholders, independence of board members and establishing committees. It should be noted that there is no a specific number of members of the board of directors, due to the different status and status of companies ${ }^{13}$.

b) The independent members of the Council

The rules governing companies are designed with one third of the board members coming from independent members (Securities Commission, 2008). Although an independent term (autonomy) was cited in the laws of companies and financial securities worldwide, there is no uniform

12 A Survey of Corporate Governance, Journal of Finance," Shleifer and Vishny. Journal of Finance, Vol. 57, pages 83737, 1997.

${ }^{13}$ Corporate governance and shareholder activity: the role of the institutional investor. Ceylon and Starks. The Journal of Financial Economics Vol. 52, number 2, pp. 275-305 (2000).

www.psychologyandeducation.net definition of this concept, as well as legislators who defined it differently from another legislator. The Securities and Exchange Commission defined the member as "a board member who does not associate him with the company or any of its senior executive management employees, an ally company, or a company auditor, any material interest or any relationship other than that related to his contribution to the company. It may have the suspicion of bringing any benefit, whether material or moral, to that member that may affect his decisions or exploit his position in the company" (Securities Commission, 2008, p. 5) ${ }^{14}$.

\section{c) Representing the legal person}

For many centuries, political, social, economic, and, before all these jurists and judges, discussed the subject of the natural person's representation as the basis of rights and duties, asset ownership, contract entry, and liability for prosecution in the name of the natural person (1999, Iwai. Article 136 of the Companies Act (1997) stipulates that a legal person shall be designated a natural person within 10 days of his or her election by the Public Authority, while Corporate governance Rules recommend that a corporate board member designate a natural person to represent him or her for the duration of the Board's term (Securities Commission, 2010) $)^{15}$.

\section{d) Separate the position of Chairman from any other executive position}

In the Middle East region, the Hawkamat is characterized by a concentration of property in few verses, which prevents separation of property, and a complete separation of property is almost unrealistic, in order to hinder it further development in the environment of the workers in need. It is therefore desirable to consider the first

\footnotetext{
${ }^{14}$ Advancing Corporate Governance in the Middle East and North Africa: Stories and Solutions", Center For International Private Corporate Governance Forum, February 2011.

${ }^{15}$ Assessing Corporate Governance in Jordan: An Empirical Study". Muhammad Shanikat and Senan S. Abbadi, The Australian Business Accounting and Finance Journal and Authors, Volume 7, Number 3, Article 7, 2011
} 
to reduce the voting rights of major shareholders to give opportunities to small shareholders and stakeholders in the decision-making process (SAIDI, 2004). The separation of the two functions can be considered a good judgment practice, because it is possible to help achieve the proper balance in the authorities and increase accountability. The Council improved its judgment on independent decision-making (Schmid and Zimmermann, 2007), so the rules of corporate governance are made that the position of chairman of the Board cannot be combined with any other executive position (the Financial Securities Commission, 2008) ${ }^{16}$.

\section{e) Experience of a board member}

The Corporate governance Rules have recommended that a board member be qualified, have sufficient knowledge of administrative matters and experience, be familiar with relevant legislation and the rights and duties of the board of directors (Securities Commission, 2008). Examples of information and experience that should characterize a board member: Experience in previous board participation, experience as senior management manager, experience in crisis management, experience in risk identification and management, experience in human resources management, good knowledge in financial and accounting matters, good knowledge of business and local and international markets (2010, IBGC) $)^{17}$.

\section{f) The functions and responsibilities of the Board member}

Shareholders of the public corporations elect the Board of Directors, thus representing all shareholders and having to exercise the

16 The Relationship Between Corporate Governance and Enterprise Value in Developing Countries: Evidence from Bangladesh", Dr. Abdul Raouf, 2011, International Journal of Applied Economics and Finance, Volume 5, Number 3, pages. 237-244, 2011.

${ }^{17}$ Bayraktaroglu, Prof. Ersoy, E. and Citak, L. "Is there a relationship between corporate governance and value-based financial performance measures? A Study on Turkey as an Emerging Market ", Asia Pacific Journal of Financial Studies, Vol. 41, Issue 2, pp. 224-239. (2012). professional care necessary to achieve the interests, objectives of the Company, since the Board is the supreme authority within the organizational structure of any public corporation. The Board of Directors had a number of functions and responsibilities previously provided for in legislation such as the Companies Act and the Securities Act, and were subsequently recommended by corporate governance rules. Among the tasks and responsibilities of the board of directors are the development of an internal system that is reviewed annually, by which the functions, powers and responsibilities of the board are defined in detail, a policy to manage the risks faced by the company, a policy of disclosure and transparency for the company and follow-up its application. It also develops various policies governing relationships with stakeholders, and the Board of Directors reviews and evaluates the performance and application of the company's executive management of the strategies, policies, plans and procedures developed. The rules also recommend written working procedures for the application, review, and annual evaluation of good corporate governance rules in the company (Securities and Exchange Commission, 2008) ${ }^{18}$.

\section{Rules relating to meetings of the General Authority}

The General Authority shall consist of all eligible contributors and shall hold a regular meeting at least once a year on the basis of the provisions of the Companies Act (1997) (Article 169), to be held during the four months following the end of the Company's financial year. The rules of corporate governance recommended that each contributor be invited to attend the meeting of the General Assembly either by hand or by regular mail or by the contributor's e-mail 21 days before the scheduled date of the meeting.

Companies should encourage participation by shareholders in meetings of the General Authority.

${ }^{18}$ Brown, LD, ML Kaylor. Corporate governance and corporate valuation. Journal of Accounting and Public Policy Volume 25 Issue (4) p. (2006). 
As result, some companies have enabled shareholders to put items on the agenda by facilitating the process of making proposals for amendment or decision and by using improvements to facilitate the process of asking questions from shareholders before the meeting of the General Authority and getting a response from the Administration and the members of the Board $(2004, \mathrm{OECD})^{19}$.

The guiding rules refer to the subject of the profile of shareholders who wish to be nominated and that they must submit it before the end of the company's financial year, which precedes the year in which the meeting of the General Authority for the election of the Council will be held. The board must attach the profile of the shareholder who wishes to be nominated for board membership to the invitation to shareholders to attend the meeting of the General Authority (Securities Commission, 2008).

\section{Rules relating to shareholder rights}

The protection of equity is an important matter provided by the legislation in the Companies Act and has provided corporate governance to confirm existing rights and add some rights as guidelines for the optimal application of corporate governance, and the corporate governance Guide divides equity into two types:

\section{a) General rights :}

Stock investors have certain equity rights, for example, a stock that represents an ownership interest in a publicly traded company can be purchased, sold, or transferred. Equity also entitles the investor to participate in the company's profits with a limited commitment to the value of his investment, and in addition, ownership of the stock gives the right to obtain information about the company and the right to influence the company by participating in and voting in the

\footnotetext{
19 Cadbury, A., Report of the Committee on the Financial Aspects of Corporate Governance, (1992) Gee \& Co Ltd, UK, London.
}

meetings of the General Shareholder Authority $(\mathrm{OECD}, 2004)^{20}$.

In other words, the general rights are to participate and vote in the meeting of the company's public authority with the number of votes equal to the number of shares owned by the shareholder, to obtain profits and priority of subscription to new shares. In addition to sue for any damages resulting from the violation of the instructions, to request meetings, and to consult the minutes of the meetings of the company's public authority, to consult the company's documentation under the legislation in force (Securities Commission, $2008)^{21}$.

\section{b) Rights within the powers of the General} Authority:

As for the rights under the broad powers of the public authority, the decision-making power is one of the first authorities as it directly affects the future of the company, these rights include the board discussion on the company's performance and plan for the next period, the election of the board members, and the election of the external auditor. In addition to the approval of the company's financial statements, the amendment of the establishment contract and the company's statute, especially with regard to changing its main aims, matters related to the company's merging, or liquidation, and the sale of the company or the ownership of another company in whole. In addition to raising or reducing, the company's capital, issuing a transferable loan to shares, taking the company's employees to share its capital, buying its shares and selling those shares. All these rules are governed by the Jordanian Companies Act (1997) with the text of Articles 171 and 175 except for the following

${ }^{20}$ Connelly, J. Limpaphayom, P. and Nagarajan, N. "Form vs. Substance: The Influence of Ownership Structure and Corporate Governance on Enterprise Value in Thailand", Journal of Banking and Financial Services Flight. 36 Number 6 June, p. 1722-1743 (2012)

${ }^{21}$ CFA Institute, Corporate Governance for Listed Companies: A Guide for Investors, Charlottesville, (2005) Virginia: Center for Financial Market Integrity, CFA Institute.

www.psychologyandeducation.net 
guiding rule, which states that the General Authority has the power to sell the entire assets of the Company or an important part that may affect the achievement of the Company objectives. This rule is indicative of the optimal application of corporate governance, since no previous legislation has provided for this rule (the Securities Commission, 2010) ${ }^{22}$.

\section{Rules relating to disclosure and transparency}

The corporate governance framework should ensure the proper timing and validity of disclosure for all matters related to the company, including company objectives, core issues involving stakeholders, disclosure of senior owners and voting rights, and the OECD has determined that disclosure should be at a minimum annual, semiannual, or quarterly level. Material information that has been deleted or misrepresented and that can affect users' decisions should be disclosed and disclosed simultaneously to all stakeholders, but this process should not create additional burdens.

\section{a) The responsibilities of the Audit} Committee

The Audit Committee is responsible for examining and reviewing internal control procedures and ensuring their effectiveness, evaluating administrative procedures to ensure compliance with rules and regulations, examining and reviewing applicable accounting policies and procedures for the preparation of actual and estimated financial statements, examining and evaluating internal audits, and reviewing the external auditor's work and proposing and setting its rates. It is also important to verify that the company's management has responded to the observations and recommendations of the External Auditor and the Securities Commission and that the corporate governance rules in this regard are applied in an optimal manner, the Audit

\section{${ }^{22}$ Cornelius, P. "Good Business Practices in Poor} Management Systems: Some Evidence from the Global Competitiveness Report." Corporate Governance $5, \mathrm{n}^{\circ} 3$ : 12-23 (2005).

www.psychologyandeducation.net
Committee must review all of the company's lines of defense and examine all its interactions with the relevant parties ${ }^{23}$.

\section{b) External Auditor}

It is essential for each company to have audited financial statements from even an independent external auditor, whose main task is to determine whether the data reflects all the essential aspects of the company, and that these data are developed in accordance with the general reporting frameworks and standards in force. It also reviews and evaluates the company's internal oversight as an integral part of the work of independent auditors. Information users see the auditor's report as an indicator of the reliability of financial statements when making their decisions ${ }^{24}$.

Corporate governance rules have emphasized how to choose the auditor and how long the audit of the company should take place. The independence of the auditor and the failure of the board of directors on the other hand, executive management to act the conditions and duties of the auditor.

\section{\# Conclusion}

In this study, we reviewed corporate governance, or as some call it good corporate governance while others call it institutional control. Corporate governance is a set of standards that deepen the role of corporate governance. In other words: "A set of legal procedures shall apply to persons of moral character, in particular to contributing companies, and shall be bound by them to ensure the proper functioning of their management, in a manner that is fair in all aspects of administration, and in such a way that profits are distributed equally to all shareholders."

23 Baigneuse, A. The 1993 law on companies and the duties of directors: small and medium-sized entities are not well supported. (2006) (Accounting Department Working Paper Series, No. 90). Hamilton, New Zealand: University of Waikato.

${ }^{24}$ Azim, M., "Corporate Governance Mechanisms and Their Impact on Company Performance: An Analysis of the Structural Equation Model”, Australian Journal of Management vol. No 37. 3 pages 481-505. (2012). 
The principles of corporate governance are originally guiding principles and are not binding, and the aim of them is to provide directions and suggestions for national legislation so that they constitute a reference that can be relied upon by economic, legislative and regulatory policy makers in a manner consistent with the legal environment of each country. The Jordanian legislator has the right to review and amend corporate law legislation in light of the development of the modern concept of corporate governance. Corporate governance is no longer an intellectual and administrative luxury. Rather, it has become a basic requirement for socioeconomic policy and it enables investors to measure the strength of the regional market and the possibility of investing in it.

Corporate governance is an effective control tool to combat corruption and slack inside the enterprise and it works to preserve the rights of shareholders and other related parties, in order to avoid the company from faltering and deviation, and to limit the bankruptcy of companies, and their liquidation. Its

implementation can achieve corporate competitiveness, preserve the rights of shareholders, and increase their profitability.

After all, corporate governance depends on public-private cooperation to create a competitive market system in a democratic society based on law and the state of enterprise, and to make the region more attractive to foreign direct investment.

\section{References}

[1] A Survey of Corporate Governance, Journal of Finance," Shleifer and Vishny. Journal of Finance, Vol. 57, pages 83-737, 1997.

[2] Abdel Sabour Abdel Qawi Ali Masri, Legal Regulation for Corporate Governance - A Comparative Study - pg. 11.Khushal Vibhute and Filipos Aynalem,

www.psychologyandeducation.net
"Legal Research Methodology.” Chilot Word Press, (2009), 23.

[3] Abdul Raouf, The Relationship Between Corporate Governance and Enterprise Value in Developing Countries: Evidence from Bangladesh",2011, International Journal of Applied Economics and Finance, Volume 5, Number 3, pages. 237244, 2011.

[4] Advancing Corporate Governance in the Middle East and North Africa: Stories and Solutions", Center For International Private Corporate Governance Forum, February 2011.

[5] Assessing Corporate Governance in Jordan: An Empirical Study". Muhammad Shanikat and Senan S. Abbadi, The Australian Business Accounting and Finance Journal and Authors, Volume 7, Number 3, Article 7, 2011

[6] Azim, M., "Corporate Governance Mechanisms and Their Impact on Company Performance: An Analysis of the Structural Equation Model", Australian Journal of Management vol. No 37. 3 pages 481-505. (2012).

[7] Baigneuse, A. The 1993 law on companies and the duties of directors: small and medium-sized entities are not well supported. (2006) (Accounting Department Working Paper Series, No. 90). Hamilton, New Zealand: University of Waikato.

[8] Bayraktaroglu, Prof. Ersoy, E. and Citak, L. "Is there a relationship between corporate governance and value-based financial performance measures? A Study on Turkey as an Emerging Market ", Asia Pacific Journal of Financial Studies, Vol. 41, Issue 2, pp. 224-239. (2012).

[9] Brown, LD, ML Kaylor. Corporate governance and corporate valuation. Journal of Accounting and Public Policy Volume 25 Issue (4) p. (2006).

[10] Cadbury, A., Report of the Committee on the Financial Aspects of Corporate 
Governance, (1992) Gee \& Co Ltd, UK, London.

[11] CFA Institute, Corporate Governance for Listed Companies: A Guide for Investors, Charlottesville, (2005) Virginia: Center for Financial Market Integrity, CFA Institute.

[12] Connelly, J. Limpaphayom, P. and Nagarajan, N. "Form vs. Substance: The Influence of Ownership Structure and Corporate Governance on Enterprise Value in Thailand", Journal of Banking and Financial Services Flight. 36 Number 6 June, p. 1722-1743 (2012).

[13] Cornelius, P. "Good Business Practices in Poor Management Systems: Some Evidence from the Global Competitiveness Report." Corporate Governance 5, $\mathrm{n} \circ 3$ : 12-23 (2005).

[14] Corporate governance and shareholder activity: the role of the institutional investor. Ceylon and Starks. The Journal of Financial Economics Vol. 52, number 2, pp. 275-305 (2000).

[15] Corporate Governance Guidebook, Securities Commission, 2008

[16] Dr. Ashraf Gamal El-Din, Corporate Governance Requirements and Financial Markets, His paper submitted to the Conference on "Corporate Governance Requirements and Arab Capital Markets held in Sharm El-Sheikh, Arab Republic of Egypt, May 2017, published in the conference proceedings folder issued by the Arab Organization for Administrative Development, p. 1

[17] Dr. Mohsen Ahmed Al-Khudairi, Corporate Governance, First Edition, the Arab Nile Group, Cairo, 2015, p. 53 and beyond.

[18] Muhammad Khaled Al-Yaseen The Legal System for the Governance of Joint Stock Companies A Comparative Study of Kuwaiti and Egyptian Legislation Dar AlNahda Al-Arabiya, Cairo, 2018. Pg. 17.

[19] OCED,OCED principles of corporate governance (22) 2016, p.22

www.psychologyandeducation.net
[20] Organization for Economic Co-operation and Development (OECD) Principles of Corporate Governance 2004

[21] Saleh Al-Okdah and others, Article on Institutional Governance in Jordan Reality and Aspirations, The Third Scientific Conference of the Faculty of Economics and Administrative Sciences, Applied Sciences Private University Jordan, published in the Jordanian Journal of Applied Sciences, issued by the Private University of Applied Sciences, August 4, 2019, p. 2. 